\title{
Day Lighting Research on Double Skin Façade (DSF)
}

\author{
M. H. M. Zin, M. Jamil, N. L. N. Ibrahim, A. S. M. Tazilan
}

\begin{abstract}
Energy consumption and carbon dioxide $\left(\mathrm{CO}_{2}\right)$ emission are issues that mostly been considered to be solved vitally. As the first layer of the building component, building's façade function more than just a building's barrier but it acts as to absorb the necessary natural elements from outside as well as function as an effective interventions. DSF possesses the efficient ability in enhancing the building performance especially on day light. Most of the research studies on DSF focus on the thermal and ventilation performance while study on the day light performance should be conducted since day light acts as the premier energy to the building's performance. This paper used the literature review as the main source of this study and tabulated through series of tables and pie chart. Result shows that research on day light performance in DSF potentially create various efficient impacts to the building's performances. This study also identifies the contribution among researchers and practitioners where each of them has their own intention that indicate the benefits on adapting DSF to a building design. Type of climates, cavity width, light shelves, glass characteristics and type of DSF are some of the important elements that need to be considering in producing an efficient daylight performance. This study reveals that more research needs to be conduct among researchers and practitioners on the daylight in DSF due to the various benefits to the buildings and occupants.
\end{abstract}

Keywords: Day lighting, façade, DSF, research

\section{INTRODUCTION}

Sustainable building design is not a building style as a promotion among researcher and practitioner to show their contribution and ability. Most of the people in the building's construction industry as well as the academician agreed that sustainable building design can assimilates with human and nature to produce a sustainable living lifestyle. Due to the numerous negative impacts to the environment that produced by buildings in the construction industry, rapid movements

Revised Manuscript Received on February 05, 2020.

* Correspondence Author

M. H. M. Zin*, is with the Architecture Department, Faculty of Engineering and Built Environment, 43600 National University of Malaysia, Malaysia (phone: 012-9446404; e-mail: bay_sir_nar86@yahoo.com).

M. Jamil, is with the Architecture Department, Faculty of Engineering and Built Environment, 43600 National University of Malaysia, Malaysia (e-mail: maslinajamil@ukm.edu.my).

N. L. N. Ibrahim, is with the Architecture Department, Faculty of Engineering and Built Environment, 43600 National University of Malaysia, Malaysia (e-mail: nlni@yahoo.com).

A. S. M. Tazilan, is with the Faculty of Engineering and Built Environment, 43600 National University of Malaysia, Malaysia (e-mail: azimintazilan@ukm.edu.my).

(C) The Authors. Published by Blue Eyes Intelligence Engineering and Sciences Publication (BEIESP). This is an open access article under the CC BY-NC-ND license (http://creativecommons.org/licenses/by-nc-nd/4.0/) emerged to create an efficient and environmental friendly building's design. Carbon emission is one of the major problem that produced by buildings compared to the other components in the industry. Besides, the unsustainable building design produces more on the energy consumption hence create various negative impacts to the human and environment. Concran [3] stated that the main contributor for $\mathrm{CO}_{2}$ emission is building and consider as one of the main polluter to the environment compare to the others human made. A study done by Pomponi et al. [12] revealed that building's façade function as the effective early protector which potentially reduce the $\mathrm{CO}_{2}$ emission and energy consumption. Building's façade also known as one of the crucial building's components to control outdoor natural elements entering the interior building space. Known as one of the most important building components [11], façade acts as to absorb and protect the building. An efficient façade system needs to be apply which produce a sustainable building design as well as enhancing the environmental. Besides, sustainable facades are more than a barrier between interior and exterior where it functions as to create an active respond to the external environment and reduce energy consumption for a comfortable indoor space [1].

As one of the most important architectural element [18], DSF has a high quality to create a comfortable indoor space since it provides various advantages including to provide an effective day light. According to Aksamija [2], DSF consist of three main elements which are cavity gap that function for ventilation purposes, external and internal glass system. Rahmani et al. [14] defined DSF as a unique building's façade system that equipped with a cavity space with various depths. DSF provides as an efficient multi functions building's façade that can solve various issues on the building design performance. Hendricksen et al. [6] proved that DSF provides various solutions to the building design such as shading devices, heat remover, passive ventilation, day light penetrator and sound protector.

However, research studies on daylight performance of DSF are very limited while daylight potentially can provide a comfortable environment for the building design [2] [13] Most of the research are focus on the ventilation and thermal performance [10] compare to daylight. Daylight provides numerous benefits where it should be apply especially to produce the positive energy performance and reducing the electrical energy usage [8]. Ubbelohde [20] revealed that, daylight is consider as the major efficient method which contribute to reduce the electrical energy usage especially for the commercial building. Daylight also contributes to create a dynamic indoor environment for the occupant. Other than ventilation, the implementation of daylight can be utilized to reduce building's energy consumption [7]. 


\section{Day Lighting Research on Double Skin Façade (DSF)}

Srinivasan \& Meenambal [19] stated that, numerous studies revealed daylight as the premier natural source that increase the productivity and performance of the occupant inside the building. However, different climate's condition possesses different outdoor illuminance that influences the DSF's design features to create a quality of daylight performance. Lack of study for building with DSF in Tropical climate region since most of the research are focus on DSF in four season climate region. Due to the issue of glare and unpredictable global illuminance, the implementation of DSF faces more difficulty especially for buildings in Tropical climate area [9]. This study will discuss on the daylight performance in DSF and to identify the contributions among researchers and practitioners. Besides, this will assist as well as encourage other researchers and practitioners to explore more on the study of daylight performance in DSF.

\section{RESEARCH METHODOLOGY}

Literature review function as the main source for this study to identify all of the information related to the DSF for day light purposes. Information is tabulates and presented through table to highlight the important elements that related to the day lighting research on DSF. Beside, series of pie chart are provided that act to enhance some of the important elements for this study.

\section{REVIEW CRITERIA}

This journal uses double-blind review process, which means that both the reviewer (s) and author (s) identities concealed from the reviewers, and vice versa, throughout the review process. All submitted manuscripts are reviewed by three reviewer one from India and rest two from overseas. There should be proper comments of the reviewers for the purpose of acceptance/ rejection. There should be minimum 01 to 02 week time window for it.

\section{LITERATURE REVIEW}

Considered as the early research by using simulation approach, Viljoen et al. [21] found some of the strategies to improve daylight performances in existing mixed use building that consist of apartment and office type located in Brussel, Belgium.

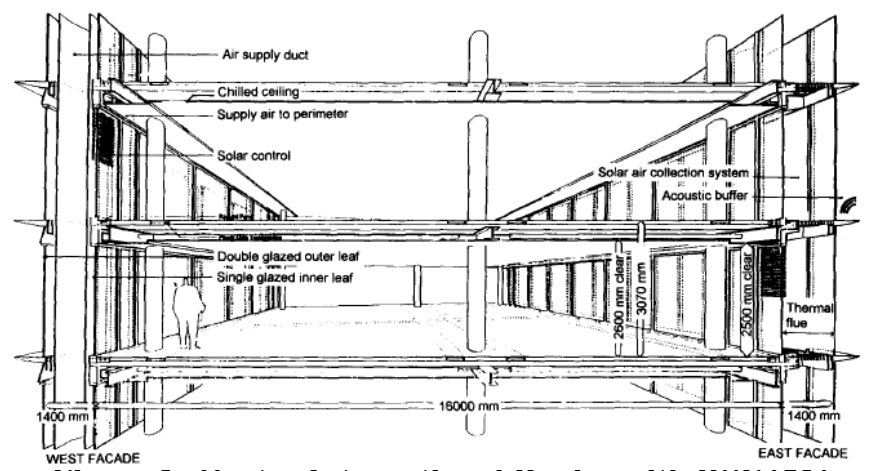

Figure 1: Centre International Rogier with USF [21].

Located within Koppen Climate region that possess mostly cool and wet condition, different strategy has been applied especially by raising up the level of walkway or also known as catwalk to $750 \mathrm{~mm}$ from the finish floor level. This research also shows that by rising up the walkway level, it

Retrieval Number: C5362029320/2020@BEIESP also functions as a light shelf that enhances the daylight performance in the building space. Besides, this strategy also need to be assists with additional requirements especially on adoption of minimum $1.4 \mathrm{~m}$ walkway depth and white color surface that enhances on the gradual daylight penetration as well as increases the day lit floor area compared to the existing day lit performance which are from $43 \%$ to $53 \%$.

Research done by Hamza \& Dudek [5] revealed the DSF daylight performance in Egypt that located in hot arid climates. As integrated subroutine in IES, Radiance acts as the software for the simulation process. Seven stories of an office building were created as the prototype to study the daylight performance as indicates in Figure 2.

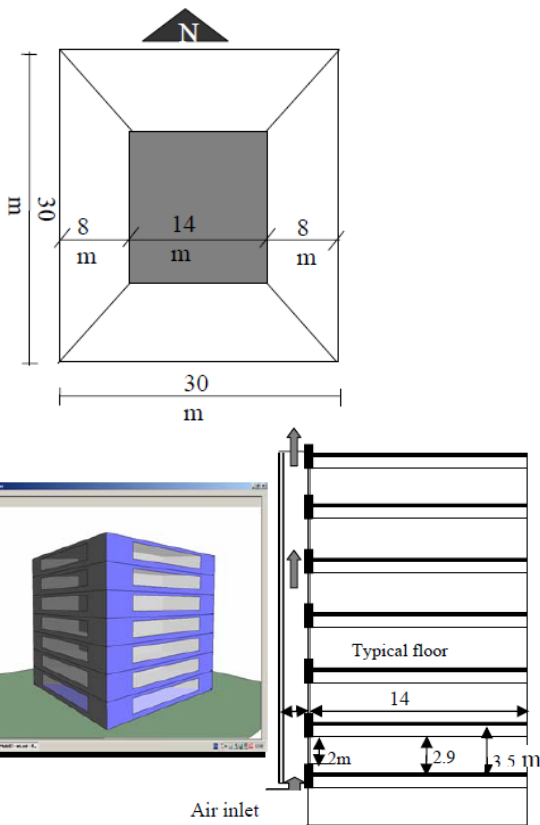

Figure 2: Floor plan, isometric and building's section [5].

This research study on the DSF glass area that focuses on four type of glass transmittance values which are 0.164 , 0.388, 0.491 and 0.891. Result shows that, 0.891 transmittance value produced the brightest daylight which is more than 450lux compared to the others. The application of DSF glass with low transmittance value creates a poor indoor daylight quality level. Moreover, selective reflective outer skin permits the high level of visible light transmission in the office space.

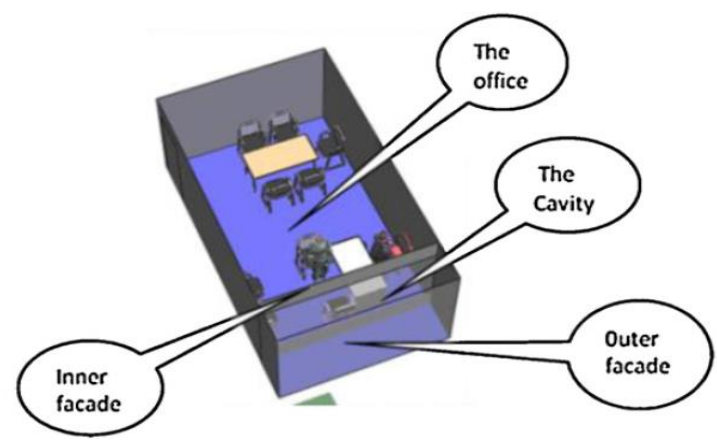

Figure 3: 3D of DSF office zone [16]

Published By:

Blue Eyes Intelligence Engineering

\& Sciences Publication 
Research done by Shameri et al. [16] revealed the advantages of adapting proper DSF design by considering the penetration of daylight to the office building. This research focuses on to study the 12 existing DSF that exposed to the different climates by using computer simulation's software known as IES. Most of the buildings were selected that base on three types of climates which are subtropical, tropical and cold climate. The implementation of DSF for building's façade require to consider the character of the environment and climate condition. Result shows that, office buildings in subtropical climate provide the highest percentage of 200lux at 19,000 lux outdoor illuminance. Unfortunately, most of the current DSF failed to provide the standard indoor illuminance requirement $(75 \%)$ of the office space.

Ghomini [4] studies the effect of cavity's depth and outdoor glass thickness to the daylight performance for educational building in hot and arid climate. By using simulation method via Lux meter and computer software known as golden surfer version 8, DSF produce more efficient daylight compare to single skin façade. Normally, daylight levels are typically high directly near to the window but will fall off rapidly with distance [15]. The implementation of DSF produce a more gradual of daylight but still failed to achieve the acceptable standard indoor illuminance between 200lux to 300lux.

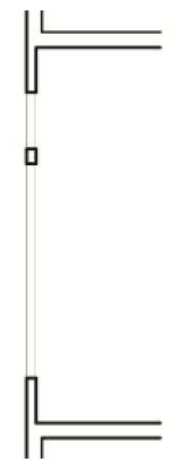

(A) Single Skin

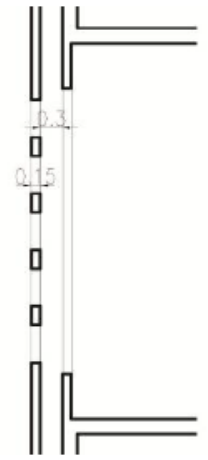

(B) Double skin with 0.15 Thick and 0.3 distances.

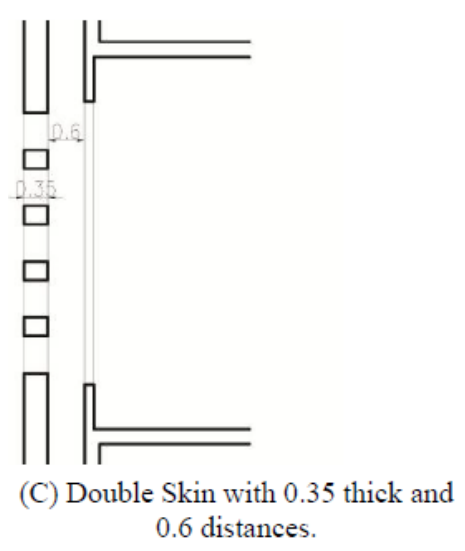

Figure 4: Differences of glass thickness for DSF [4].

As indicates in Figure 4, Aksamija [4] done a research that focus on the daylight performance to three types of DSF which are box window, corridor and multistory. Besides, this research compared the daylight performance between three typologies of DSF as mentioned previously with the single skin façade (standard curtain wall). Four cities are selected for daylight simulation in United States such as Duluth, Chicago, San Francisco and Miami where that base on different climates and latitudes. The simulation process applied by the computer software known as Radiance to calculate as well as the performance of the daylight while the simulation models were created via Revit. This research reveals that all types of DSF which are box window, corridor façade and multistory facades decreases the day light levels compared to the ingle skin façade (conventional curtain wall). Multistory DSF consistently performed to produce more quality day light. As a unique design component, cavity depth plays a vital role in DSF where multistory and corridor façade produced better performance in $0.9 \mathrm{~m}$ depth while box window produce better day light performance in $0.6 \mathrm{~m}$ depth.

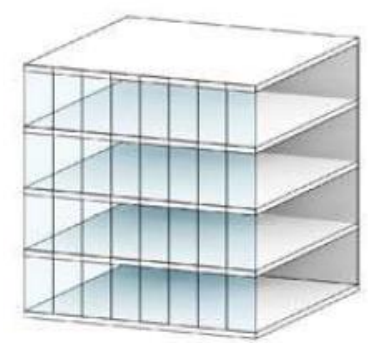

Single Skin Facade (standard curtain wall)

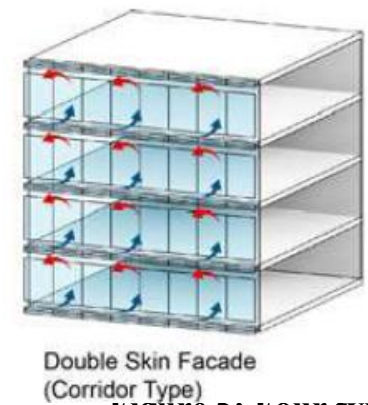
(Corridor Type)

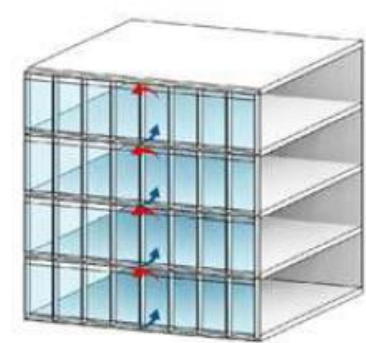

Double Skin Facade (Box-Window)

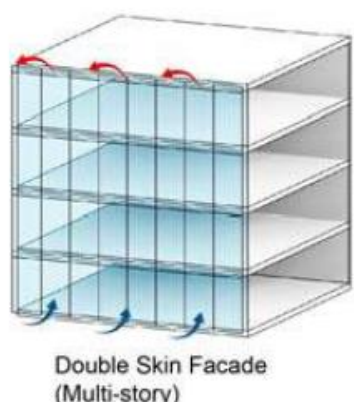
Double Skin Facad
(Multi-story)

\section{RESULTS AND DISCUSSIONS}

As indicates in Table 1, five researchers or practitioners were seriously involved in the DSF daylight performance that focuses on certain issue and objective. Study on the DSF daylight performances were started since 1997 that can be considered as the pioneer in DSF daylight simulation study which encourages the other researchers and practitioners on another important benefit of DSF. A big gap since 2001 until 2013 where none of the publications focus on the DSF daylight performance study compared to the ventilation and thermal study. Three publications on DSF daylight's study emerged in 2013 and 2017 by using a more comprehensive study and different methodology as an indicator the potential of daylight performance in DSF. 
Day Lighting Research on Double Skin Façade (DSF)

Table- I: Research on daylight performance in DSF.

\begin{tabular}{|c|c|c|c|c|c|c|c|}
\hline AUTHOR & TITLE & YEAR & METHODOLOGY & $\begin{array}{l}\text { PARAMETER } \\
\text { STUDY }\end{array}$ & $\begin{array}{l}\text { BUILDING } \\
\text { TYPE }\end{array}$ & FINDING & $\begin{array}{l}\text { CLIMATE } \\
\text { CONDITION }\end{array}$ \\
\hline Viljoen & $\begin{array}{l}\text { Investigations } \\
\text { for improving } \\
\text { the daylighting } \\
\text { potential of } \\
\text { double-skinned } \\
\text { office buildings }\end{array}$ & 1997 & $\begin{array}{l}\text { Simulation computer } \\
\text { software by using } \\
\text { Radiance in IES. }\end{array}$ & $\begin{array}{l}\text {-High of the } \\
\text { walkway } \\
\text {-Depth of the } \\
\text { walkway } \\
\text {-Type of walkway } \\
\text { reflectivity between } \\
\text { black and white } \\
\text {-Floor depth }\end{array}$ & $\begin{array}{l}\text { Mixed use } \\
\text { between } \\
\text { apartment and } \\
\text { office. }\end{array}$ & $\begin{array}{l}\text { Raising walkway at } \\
\text { 750mm with white } \\
\text { color, thin } \\
\text { perforated metal } \\
\text { sheet will increase } \\
\text { the daylit floor area. }\end{array}$ & $\begin{array}{l}\text {-Koppen } \\
\text { climate } \\
\text {-Cold and wet }\end{array}$ \\
\hline Hamza & $\begin{array}{l}\text { Thermal and } \\
\text { daylight } \\
\text { performance of } \\
\text { double skin } \\
\text { facades in hot } \\
\text { arid areas }\end{array}$ & 2001 & $\begin{array}{l}\text { Simulation computer } \\
\text { software by using } \\
\text { Radiance in IES }\end{array}$ & $\begin{array}{l}\text {-Different type of } \\
\text { DSF glass } \\
\text { transmittance value }\end{array}$ & $\begin{array}{l}\text { A prototype of } \\
\text { seven stories } \\
\text { office building }\end{array}$ & $\begin{array}{c}\text { Higher glass } \\
\text { transmittance value } \\
\text { produce brighter } \\
\text { daylight which is } \\
\text { considered more } \\
\text { than 450lux }\end{array}$ & $\begin{array}{l}\text {-Hot and arid } \\
\text { climate }\end{array}$ \\
\hline Shameri & $\begin{array}{l}\text { Daylighting } \\
\text { characteristics } \\
\text { of existing } \\
\text { double-skin } \\
\text { facade office } \\
\text { buildings }\end{array}$ & 2013 & $\begin{array}{l}\text { Simulation computer } \\
\text { software by using IES }\end{array}$ & $\begin{array}{l}\text {-Different outdoor } \\
\text { illuminance } \\
\text {-Different climate }\end{array}$ & Office building & $\begin{array}{l}\text { Most of the current } \\
\text { DSF in office } \\
\text { buildings failed to } \\
\text { meet the } 75 \% \text { of the } \\
\text { office space provide } \\
\text { with indoor } \\
\text { illuminance of } \\
\text { 200lux }\end{array}$ & $\begin{array}{l}\text {-Subtropical } \\
\text { climate } \\
\text {-Tropical } \\
\text { Climate } \\
\text {-Cold climate }\end{array}$ \\
\hline Ghonimi, I. & $\begin{array}{c}\text { Assessing } \\
\text { daylight } \\
\text { performance of } \\
\text { single vs. } \\
\text { double skin } \\
\text { facade in } \\
\text { educational } \\
\text { buildings : A } \\
\text { comparative } \\
\text { analysis of two } \\
\text { case studies } \\
\end{array}$ & 2017 & $\begin{array}{c}\text { Case study and } \\
\text { simulation by Lux } \\
\text { metre and computer } \\
\text { software Golden surfer } \\
\text { version } 8\end{array}$ & $\begin{array}{l}\text {-Single skin façade } \\
\text {-Outdoor glass } \\
\text { thickness } \\
\text {-Cavity space width }\end{array}$ & $\begin{array}{l}\text { Educational } \\
\text { building }\end{array}$ & $\begin{array}{l}\text { Gradual distribution } \\
\text { and high quality of } \\
\text { daylight produced } \\
\text { but failed to achieve } \\
\text { the acceptable } \\
\text { standard indoor } \\
\text { illuminance } \\
\text { between 200lux to } \\
\text { 300lux. }\end{array}$ & $\begin{array}{l}\text { Hot and arid } \\
\text { climate }\end{array}$ \\
\hline $\begin{array}{l}\text { Aksamija, } \\
\text { A. }\end{array}$ & $\begin{array}{l}\text { Double-skin } \\
\text { facades and } \\
\text { daylight } \\
\text { simulations: } \\
\text { Comparative } \\
\text { study of façade } \\
\text { typologies and } \\
\text { effects on } \\
\text { natural light in } \\
\text { different } \\
\text { climates. }\end{array}$ & 2017 & $\begin{array}{l}\text {-Building models were } \\
\text { created via Revit } \\
\text {-Simulation process by } \\
\text { using Radiance in IES. }\end{array}$ & $\begin{array}{l}\text {-Three types of DSF } \\
\text { such as box } \\
\text { window, corridor } \\
\text { and multistory } \\
\text {-Single skin façade } \\
\text {-Four different of } \\
\text { façade's orientation } \\
\text { (north, south, east } \\
\text { and west). } \\
\text {-Different cities } \\
\text { with different } \\
\text { climates and } \\
\text { latitudes located in } \\
\text { United States }\end{array}$ & Office building & $\begin{array}{l}\text {-All of the DSF } \\
\text { produced a better } \\
\text { day light } \\
\text { performance } \\
\text { compared to the } \\
\text { single skin façade } \\
\text { (conventional } \\
\text { curtain wall) } \\
\text {-Cavity depth play a } \\
\text { major role to } \\
\text { produce better day } \\
\text { light performance } \\
\text { in all type of DSF. }\end{array}$ & $\begin{array}{c}\text {-Humid } \\
\text { continental } \\
\text { Koppen zone } \\
\text {-Cool-summer } \\
\text { Mediterranean } \\
\text {-Koppen } \\
\text { climate zone } \\
\text {-Tropical } \\
\text { climate } \\
\text { monsoon } \\
\text { climate } \\
\text { Koppen zone. }\end{array}$ \\
\hline
\end{tabular}

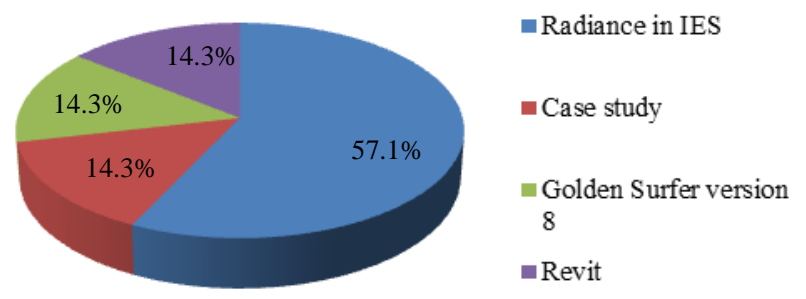

Figure 6: Type of methodology in DSF daylight performance

Base on Figure 6, four types of methodology are implemented on the five researches on DSF daylight performance. Radiance in IES software is the most significant methodology that records $57.1 \%$ to identify the daylight performance in DSF. IES is an establish computer software that being applied by most of the research that not only focus on daylight study by being applied for research in energy, thermal and ventilation. The other three types of methodology record the same percentage which is $14.3 \%$ where case study and Revit function as the additional methodology to enhance the research. Golden Surfer version 8 is computer software that applied the simulation process other than IES.

This research revealed on another type of computer simulation software that can be explored by researchers and practitioner. As mentioned before, IES is the main computer simulation among researcher especially to study the daylight performance for DSF and can be assisted by other type of methodology that depends on the research issues and objectives.

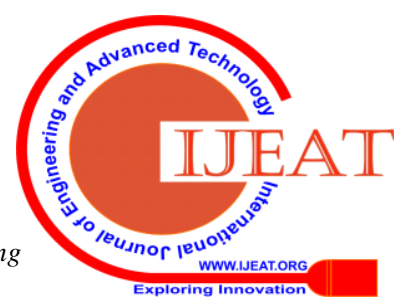




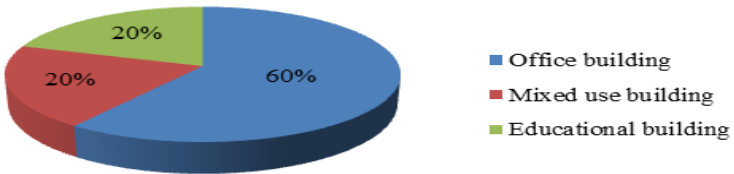

Figure 7 indicates that, most of the DSF daylight research is focusing on the office building type that records $60 \%$ while mixed use building (20\%) and educational building (20\%). Majority of researcher focus on the office building due to its function that people majority spend their daily time in an office building as similar to the home. Besides, DSF mostly been applied for office building design to reduce the energy consumption and need more study to increase the SF efficiency. Building's levels also play a major role since office building levels usually are more than 3 to 4 stories to receive more daylight as well as to create the stack effect within the cavity space.

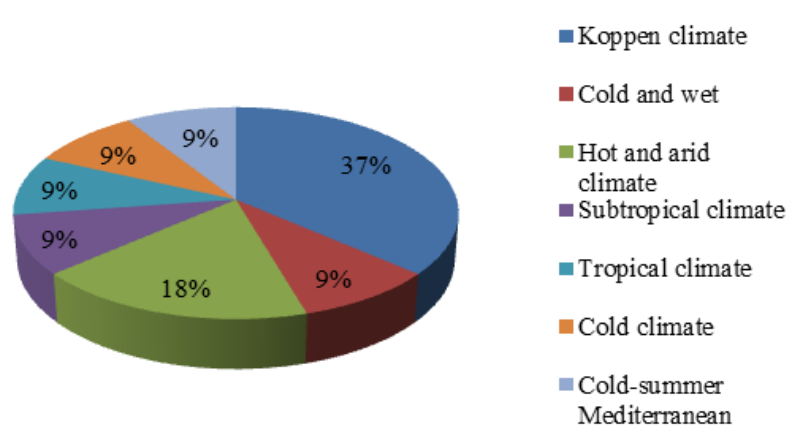

Figure 8: Type of climates in DSF daylight performance

According to Figure 8, researchers are mostly study buildings which are located within Koppen climate that record as $37 \%$. Hot and arid climate indicates as the second highest to be studied by researchers that record $18 \%$ while the other types of climate record the similar percentage which is $9 \%$. This study reveal that more study need to be conduct in other climate area as well as focus on certain component of DSF to enhance the daylight performance. Climate study acts as the vital requirements that produce different daylight's characteristics which affect the daylight performance inside the building spaces. This study does not indicate that, DSF is efficiency implemented in Koppen climate as well as hot and arid climate. It shows the lacking of study on DSF daylight performance in majority of the climates compared to ventilation and thermal study.

\section{CONCLUSSION}

The contents of the journal are peer-reviewed and archival. The journal publishes scholarly articles of archival value as well as tutorial expositions and critical reviews of classical subjects and topics of current interest.

Authors should consider the following points:
Figure 7: Type of buildings in DSF daylight
performance

1) Technical papers submitted for publication must advance the state of knowledge and must cite relevant prior work.

2) The length of a submitted paper should be commensurate with the importance, or appropriate to the complexity, of the work. For example, an obvious extension of previously published work might not be appropriate for publication or might be adequately treated in just a few pages.

3) Authors must convince both peer reviewers and the editors of the scientific and technical merit of a paper; the standards of proof are higher when extraordinary or unexpected results are reported.

4) Because replication is required for scientific progress, papers submitted for publication must provide sufficient information to allow readers to perform similar experiments or calculations and use the reported results. Although not everything need be disclosed, a paper must contain new, useable, and fully described information. For example, a specimen's chemical composition need not be reported if the main purpose of a paper is to introduce a new measurement technique. Authors should expect to be challenged by reviewers if the results are not supported by adequate data and critical details.

\section{CONCLUSION}

In conclusion, all aspects for day light application in DSF design are summarized as follows:

1) Different climates provide different characteristics to produce an efficient day light system in DSF. A thorough study and deep understanding on the climates condition can consider as the main priority that work simultaneously with DSF design study.

2) Floor depth need to be considered to produce a quality of daylight performance where it is necessary to be integrated with DSF design. Besides, to create an efficient DSF design that produces a better daylight, floor depth comes together with ceiling height that will influence the daylight penetration especially for spaces that located far from the original façade.

3) Cavity space acts as the main component for DSF that assisted by other components such as walkway or catwalk, light shelves, inner and exterior glass façade. Cavity depth produces different daylight performance that influences by the climates condition.

4) Since DSF is compared to the conventional curtain wall façade or single glass façade, glass selection for inner and exterior façade also influence the daylight performance. The glass selection is based on the typology, thickness, and transmittance and reflection value as the criteria that need to be considered to enhance the application of daylight in DSF.

5) Majority of the methodology, applied through the computer simulation process with various software especially Radiance in IES including existing building and prototype building with DSF. Various data were produced that assist researchers and practitioners received the actual daylight's performance for DSF.

6) Three types of DSF create distinct of daylight performance compared to the single glass façade design.

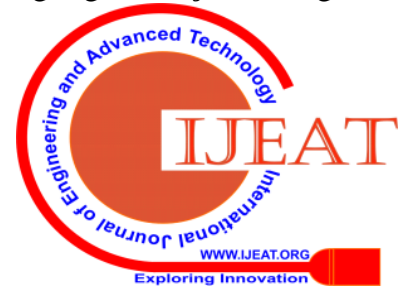




\section{Day Lighting Research on Double Skin Façade (DSF)}

Thorough studies on the other requirements potentially enhance the DSF performance especially on the climates characteristic and other DSF's components.

Further study on day light for DSF need to be enhances by the researchers and practitioners. As we know, most of the study on DSF is focus on the thermal and ventilation system and daylight would be another benefit to increase the DSF's efficiency. The lacking part on daylight study should encourage researchers and practitioners to find the best design criteria which enhance the daylight performance for DSF with different climates condition.

\section{ACKNOWLEDGMENT}

The authors thank the Universiti Kebangsaan Malaysia (DIP-2016-006) and Ministry of Education (MyPhd and FRGS/1/2017/TK06/UKM/02/2) for proving their financial support which made this study possible.

\section{REFERENCES}

1. Aksamija, A. 2015. Design methods for sustainable, high-performance building facades. Advances in Building Energy Research 10(2) : 240-262

2. Aksamija, A. 2017. Double-skin facades and daylight simulations: Comparative study of façade typologies and effects on natural light in different climates. Proceedings of the Symposium on Simulation for Architecture and Urban Design : 203-210

3. Concran, T. 2009. Eco house book. London: Conran Octopus Ltd.

4. Ghonimi, I. 2017. Assessing daylight performance of single vs. double skin facade in educational buildings : A comparative analysis of two case studies. Journal of Sustainable Development 10(3) : 133-142.

5. Hamza, N., Dudek, S. \& Elkadi, H. 2001. Thermal and daylight performance of double skin facades in hot arid areas. Conference: 8th REHVA World Congress Clima 2001, Ottawa, Canada, July 23-27.

6. Hendriksen, O.J., Sorensen, H., Svensson, A. \& Aaqvist, P. 2000 Double skin facades - Fashion or a step towards sustianble buildings. International Soalr Energy.

7. Ibrahim, N. \& Zain-Ahmed, A. 2006. Energy saving due to daylighting : A simplified rediction tool for wall envelope design of air-conditioned office buildings in Malaysia. 3(1) : 63-75.

8. Konis, K. 2013. Evaluating daylight effectiveness and occupant visual comfort in a side-lit open-plan office building in San Francisco, California.

9. Lim, Y. W., \& Ahmad, M, H. 2013. Daylighting as a sustainable approach for high-rise office in Tropics. International Journal of Real Estate Studies 8(1) : 30-42.

10. Lou, W., Huang, M., Zhang, M., \& Lin, N. 2012. Experimental and zonal modeling for wind pressures on double-skin facades of atall building. Energy and Buildings 54(2012) : 179-191.

11. Nejadriahi, H. 2017. Role of facade in sustainability enhancement of contemporary Iranian buildings. International Scholarly and Scientific Research \& Innovation 11(6) : 729-733.

12. Pomponi, F., Piroozfar, P.A.E., Southall, R., Ashton, P. \& Farr, E. R.P. 2015. Life cycle energy and carbon assessment of double skin facades for office refurbishments. Energy and Buildings 109(2015) : 143-156.

13. Pomponi, F., Piroozfar, P.A.E., Southall, R., Ashton, P. \& Farr, E.R.P. 2016. Energy performance of double-skin facades in temperate climates: A systematic review and meta-analysis. Rnewable and Sustainable Energy Reviews 54(2016) : 1525-1536.

14. Rahmani, B., Kandar, M.Z., Rahmani, P. 2012. How double skin facade's air-gap sizes effect on lowering solar heat gain in tropical climate?. World Applied Sciences Journal 18(6) : 774-778

15. Schepers, H., Clintock, M. M. \& Perry, J. 2001. Dayligh design for tropical facades. Center for Window and Cladding Technology 77-84.

16. Shameri, M.A., Alghoul, M.A., Sopian, K., M. Zain, \& Elayeb, O. 2011.Perspective of double skin facade systems in buildings and energy saving. Renewable and Sustainable Energy Reviews 15(2011): 1468-1475.

17. Shameri, M.A., Alghoul, M.A., Elayeb, O., M. Zain, M.F., Alrubaih, M.S., Amir, H. \& Sopian, K. 2013. Daylighting characteristics of existing double-skin facade office buildings. Energy and Buildings 59(2013): 279-286

18. Streicher, W. 2005. Best practise for double skin facade. Austria: Intelligent Energy Europe.

M. H. M. Zin, is a PhD student at the Architecture Department of Faculty Engineering and Built Environment in Universiti Kebangsaan Malaysia (UKM). He graduated his Bachelor in Architecture in 2010 and Master Science in Architecture in 2013 from Universiti Kebangsaan Malaysia (UKM).

M. Jamil, is an Associate Professor at the Architecture Department, Faculty Engineering and Built Environment in Universiti Kebangsaan Malaysia (UKM).

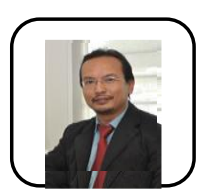

N. L. N. Ibrahim, is an Associate Professor at the Architecture Department, Faculty Engineering and Built Environment in Universiti Kebangsaan Malaysia (UKM).

A. S. M. Tazilan, is an Associate Professor at the Architecture Department, Faculty Engineering and Built Environment in Universiti Kebangsaan Malaysia (UKM). 